\title{
CAMPAIGN COMMUNICATION IN NIGERIA'S 2019 GENERAL ELECTIONS \\ Unfulfilled Party Pledges and Voter Engagement without a Social Contract
}

\section{Mike Omilusi}

Mike Omilusi is a lecturer in the Department of Political Science, Ekiti State University, Nigeria

\begin{abstract}
Broken campaign promises challenge the sanctity of the electoral process in Nigeria. Six decades after political independence and six electoral cycles in the last two decades of the Fourth Republic, there are inadequate legal frameworks and a lack of political will to change the narrative. Ambushing the voters with plans of action on the eve of every election remains a constant ritual to legitimise party campaigns in both digital media and at heavily mobilised rallies, often with limited substance. The general purpose of this study is twofold. First, to provide analysis of campaign communication and the extent to which it influences the participation of citizens in the electoral process. Second, to investigate the electorate's understanding of policy issues inherent in the 2019 election manifestos of the two dominant political parties, All Progressive Congress (APC) and People's Democratic Party (PDP), and how other elements shape perception and trust in elected representatives/ government. The research design relies on sample surveys and in-depth interviews, and seeks to identify, within the context of an electoral cycle, why conversations between public office seekers and voters do not translate into a concrete social contract or generate time-bound inclusive policies.
\end{abstract}

Keywords: social contract, elections, democracy, campaign communication

\section{INTRODUCTION}

Political campaign communication encapsulates three important areas in political campaigns: providing reasons for voters to retain faith in the political 
system; providing citizens the freedom to select their leaders; and providing the opportunity to evaluate how their interests can be best served while conferring legitimacy on those elected to govern (Trent \& Friedenberg 2004). In many parts of the world, the issues and debates of electoral campaigns provide insight into societies' priorities and aspirations (Svetlik 2018). Seeking voters' support during election campaigns should be an open debate with reasoned arguments about which particular political candidates are most competent for the office sought (Heywood 2007). This is better done by 'presenting programs of public good to stake out competitive positions by persuading the median voter at the centre of the political spectrum' (Nichter 2008, p. 42).

A crucial factor in the legitimisation of modern democracies is the degree to which policies presented to the public before an election translate into tangible end results once a political party wins power (Brouard et al. 2018). This is because 'periodic and genuine elections are generally seen as a key component for enhancing the legitimacy of a government and strengthening the social contract between the government and the governed' (UNDP 2016, p.12). The primary reason for the existence of parties is to contest and capture state power - ideally through peaceful means - in regular multiparty elections (Matlosa 2007) where pledges are made to the electorate. Existing empirical work indicates that campaign promises are important for voter evaluations, both prospectively and retrospectively (Bonilla 2017). Suffice to say that party campaigns provide a platform for exposing the electorate to competing ideas about how to run the country for their wellbeing. This may be done through open rallies and organised debates among contestants for public office (The Guardian 2019).

Thus, the extent to which government actions fulfil election promises has continually raised an important scholarly debate (Petry \& Collette 2009). While a manifesto may give government a mandate for its policies, it is likely to contain a host of commitments and most voters will be aware of only a small number (Bogdanor 2015). Even politicians assume that manifestos are often not well suited for distribution to voters (Eder et al. 2017). The percentage of voters that reads party manifestos is negligible, perhaps because voters are frequently cynical about politicians' promises.

In Nigeria, electoral promises are often not kept, which is an obvious challenge to the sanctity of the electoral process. Unfulfilled campaign promises remain a seemingly intractable challenge, perhaps because the process itself is vulnerable to manipulation. Nearly six decades after independence, there seems to be an inadequate legal framework and political will to change the narrative. Ambushing voters with plans of action on the eve of every election year remains a constant ritual to formally legitimise party campaigns in the digital media and at heavily mobilised rallies, often with limited substance. Each election precipitates 
a mobilisation of the people but the promised social contract is ephemeral. Hence, successive ruling parties project policy blueprints but continually fail to represent Nigerians' concerns or meet their needs. The citizens too seem unable to hold government accountable while there is no reliable system to anchor activism. Electoral brigandage that has gone unpunished has created disillusion and elections are approached cynically. When disillusioned voters are courted by parties and politicians only on the eve of a general election, it is doubtful whether such periodic engagement can engender more democratic and people-driven party politics and credible electoral processes in the country.

In the 2019 general elections, presidential candidates unveiled policy documents less than three months prior to scheduled polls, and even with organised presidential debates there was little to provoke electoral change among voters. In reality, the voters were not presented with making a choice among viable candidates, but with choosing the lesser of two evils. The contest narrowed down to the incumbent - seen by many as ineffective but honest and well-meaning - and the main opposition candidate, seen as corrupt and buccaneering.

Previous studies by Hampshire (2016) and Bogdanor (2015) have found that the positive effect of an electoral manifesto possibly misconstrued or misinterpreted the peculiarities of Nigeria's political environment and misunderstood the character of Nigerian politicians. This study, therefore, recommends a significant investment to rebuild the social contract and broaden the democratic focus from a merely 'successful' transition (from one administration to another, or from one faction of the ruling elite to another) to a sustainable democracy that delivers on promises. This would involve the constructive engagement of citizens to engender greater transparency in public affairs; promote government accountability; and enhance trust in the political process.

\section{RESEARCH}

From a theoretical perspective, fulfilling electoral pledges is an important aspect of the envisaged congruence between the pre- and post-electoral policy contents of political parties' manifestos. Political party manifestos - the key policy statements of political parties in an election - have become a research interest to many scholars in Africa. Research on whether voters understand electoral programmes or trust their implementation is very 'limited because data is scarce, for example, the consumption and knowledge of electoral manifestos is rarely addressed in election surveys' (Rölle 2002, p.43). Political parties, which exist to channel political frustration in other countries, are historically weak in Nigeria, particularly after the First Republic. They 'have little institutional structure and often maintain superficial connections with communities' (Campbell 2011). The differences 
between them are more in nomenclature, size, and geographical spread. There is almost no clear-cut difference in the vision and mission of Nigerian political parties, and party manifestos reflect a drab similarity. However, there is no alternative institution to usurp the role of political parties in a representative and multiparty democracy. Hence, in the absence of ideological differences among the political parties, aspiring public office-holders identify with party platforms based on which could best help them achieve their ambitions. This is one reason for the frequent defections that have plagued the system.

In most African states, political leaders often sign election and pre-election pacts, codes of conduct, agreements or even peace pledges, 'promising to safeguard peace and the interests of their supporters and voters before and after elections' (Maphunye 2016, p.15). Such pacts, usually drawn up at the instance of international organisations and civil society coalitions, are designed for candidates to accept election results, or not to instigate their followers in the interest of the country; but significantly they are not a binding contract meant to commit parties/ candidates to honour campaign pledges after election. A chronic decline in the political system's capacity for self-organisation seems to have set in, with the media, political parties, civil society activists and trade unions unable to hold career politicians accountable and prevent them from pursuing naked self-interest.

\section{Research Questions}

Twenty years after Nigeria terminated military authoritarianism and resumed civilian rule, the country held its arguably most competitive presidential election in February 2019. President Muhammadu Buhari and former Vice President Atiku Abubakar, both of whom are from Northern Nigeria, were the two most popular presidential candidates in an election that paraded 73 candidates for the country's highest office. The two major contenders offered the electorate contrasting visions on the economy, corruption, security, and federalism (Devermont 2019, p. 21). With this background, the current study seeks to address the following research questions:

- Under what circumstances do campaign communications, through rallies and digital platforms, engender increased levels of engagement among citizens?

- How can public institutions deliver on the mandates of their offices and provide public goods and services through transparent and responsive governance?

- What are the mechanisms that guarantee that government measures up to the public trust by delivering on its promises? 
- What are the usual responses of voters to the mobilisation techniques of political parties and candidates?

- While campaign promises may not be regarded as a binding contract, and thus not enforceable, how can prospective voters meaningfully engage candidates to make commitments?

\section{Objectives of the Study}

The general purpose of this study is twofold. First, to provide analysis of campaign communication and the extent to which it influences the participation of citizens in the electoral process. Second, to interrogate the electorate's understanding of the policy issues inherent in the 2019 election manifestos of the two dominant political parties, All Progressive Congress (APC) and People's Democratic Party (PDP), and to understand how other important elements shape people's perception and trust in elected representatives/government.

The research design, relying on sample surveys augmented by qualitative research and in-depth interviews, seeks to identify factors within the context of an electoral circle as to why conversations between public office seekers and voters do not translate into concrete social contracts or generate time-bound inclusive policies. Other specific objectives of this study are:

- To examine voters' understanding of political parties' manifestos and their level of trust in office-seeking candidates;

- To assess if political communication through rallies and digital platforms can lead to enhanced levels of engagement among Nigerian citizens;

- To interrogate the strategies employed by political parties and candidates to disseminate messages and influence voters, focusing on the responses of voters to these mobilisation techniques;

- To examine the voters' perception of post-election policy implementation by parties and candidates; and

- To explore practicable modalities of committing political parties and candidates to a social contract with the people.

\section{Methodology}

This study is designed to provide an overview of current and recent research on election campaigning and party-political communication, using desk study, surveys and participant-observation methods of data gathering. The integrity and accuracy, or otherwise, of the debates held during the campaign become 
critical. The study is grounded in engagement with people of concern and relevant stakeholders, through an online survey (356 respondents) and key interviews (11 respondents) in South Western Nigeria with a view to eliciting information regarding the subject matter. Information from secondary sources include library and archival documents, monographs, journals, materials from the Internet, government publications, newspapers, magazines and periodicals.

\section{Significance of the Study}

Ideally, elections serve as a 'major source of political recruitment, a means of making government, and of transferring government power, a guarantee of representation, and a major determinant of government policy' (Heywood 2000, p.75). More importantly, a well-conducted campaign and election showcase the vitality and quality of a democracy because communications by political parties and discussions among citizens lie at the heart of electoral campaigns. For this reason, deeper, more comprehensive and reliable analyses are required for a better understanding of how the process works, and how it could be modified for the best outcomes.

A considerable body of literature is concerned with the electoral manifesto and political party communication. However, a novel aspect of this study is that it will provide rigorous evidence regarding policy assessment and trust in implementation from the perspective of voters and politicians during campaign and post-electoral periods. Election pledge research is imperative given that only some of the policy proposals discussed before elections by political parties end up in election manifestos. While there has been some research into party communication during elections, there has been little on how to measure Nigerian voters' understanding of, and trust in, election pledges by political parties. Taking into account that public trust in government depends largely on the success or failure of its policies and how accountable electoral representatives are, the knowledge of this aspect can inform both the academic study of party politics and political practice.

\section{PARTY POLITICS, CAMPAIGN PROMISES AND VOTER EXPECTATIONS}

Politicians seeking office make promises they intend to implement if elected in the belief that such promises will engender voters' trust in their capabilities (Aragonès et al. 2007). Due to the improvement in information and communication technology, digital and multi-media are used to inform and persuade the public. During special events such as election campaigns, politicians and political parties spend fortunes on advertising slogans such as 'make Nigeria work again', 'put 
smile on the poor faces', 'make life meaningful for our people', 'take Nigerians to the next level', or 'bring back our lost glory'. Such slogans are largely platitudes not backed with ideological or policy development contents. On capturing state power, these politicians felt no obligation to implement vague statements of intent; nor did the electorate call them to account. Vaguer promises and vituperative comments about opponents were made by political parties in the next round of elections in what had become a periodic ritual. A cynical electorate tried to get the dividends of democracy upfront by demanding gratification at every step of the process. Needless to say, political parties in Nigeria today are among the least trusted institutions. Van Reybrouck's (2016 p. 7) submission in this regard is apt:

Since we have reduced democracy to selecting representatives, and reduced representative democracy to mean simply voting, a valuable system is now mired in deep difficulties. Winning the next election has become more important than fulfilling the promises made in the last.

In developing democracies, electoral campaigns tend to involve electing political leaders on the basis of personal characteristics. Another significant driver 'in electoral dynamics can be identity-based backgrounds that link competing parties to groups of voters on grounds other than issues, such as patrimonial relationships (inheritances) or clientelism (patronage)' (Jansen et al. 2016, p. 38). In Africa, where accountability in governance processes remains elusive, many political leaders may overlook or ignore their electoral mandate once they are elected into office (Maphunye 2016). Politics in Nigeria specifically is dominated by personality, not by issues, and politicians frequently and easily shift from one party to the other (Campbell 2018). The social media space in the country is vulnerable to manipulation by influential politicians who are ready to deploy their agents on social media in order to confuse and divide the people along ethnic, religious or other fault-lines to serve their vested interests (Hassan 2018).

\section{PRESIDENTIAL CANDIDATES AND PARTY CAMPAIGN STRATEGIES}

Ordinarily, election manifestos should represent values and opportunities for progress and change in the society. Manifestos 'are ideally a product of a negotiated process by different actors and groups within each political party and offer an official statement of a party's policy proposals' (Mubanga 2016, p.32). Manifestos should also outline the problems and issues which a political party presents to the public during the elections. But on close examination, the manifestos of political parties in Nigeria are not distinctive from each other in their approach to the core issues, policies and programmes. 
Nigerians were bombarded with pledges, slogans and social media messages months before the 2019 general elections. Candidates attempted to present their different programmes through rallies, statements to the media and in televised debates. After the party primary conventions in September 2018, millions of party members and supporters embarked on a massive social media campaign that galvanised support in a country where social media usage and activity have become a household obsession.

The two leading candidates of the APC and PDP dominated the political space and campaigns. Apart from the presidential debate that featured three other parties and scanty media interviews, the remaining candidates operated on the periphery. Indeed, the reluctance of the big parties to physically get in touch with grassroots electorate, relying mostly on electronic and newspaper advertisements, made it difficult for undecided, rural voters, to feel confident about them. Where these dominant parties organised public campaign rallies, effective communication could not be said to have taken place. The field experience below sums up the dominant narrative of citizen engagement in political mobilisation/ campaign communication and the gradual decline in the quality of participatory democracy and legitimacy in Nigeria:

Along the dusty road that sunny afternoon, just as we were trying to catch up with people at the venue of a political rally, we met a young man - obviously a party loyalist judging by his customised T-shirt and cap and the enthusiasm with which he spoke to us. Having introduced ourselves as researchers, we requested to know the happenings around the venue, particularly about his party manifesto and its possible efficacy as an instrument of mobilisation. His smug response was: This (rally) is just to show them that we are in town; the election is won already even without manifesto. Two hours after the rally, we questioned an old woman/ retiree about what she thought about the message of the politicians, being one of the attendees. She said: The politicians spoke on our behalf as if they knew our minds. They all made many promises without bothering to know our agitations. Thank God, my tenant delivered their message by giving me transport fare.

(Personal communication, 22 January 2020)

While unveiling his manifesto, President Buhari promised to sustain the anticorruption war, provide more infrastructures and rebuild the economy. According to him: 'We are committed to deepening the work we started this first term such that the nation's assets and resources continue to be organised and utilised to do good for the common man' (Mumbere 2018, p. 4). In his campaign document entitled, The Next Level: Working for the Greatest Number, Buhari said 'actions like 
placing all government revenues and funds recovered in corruption investigations into the Treasury Single Account (TSA), have cushioned the country from oil dependency' (Mumbere 2018, p. 4). The president also planned to re-double the anti-insurgency war, build one industrial hub per geopolitical zone and one value processing plant in each senatorial district (Ajaja 2018). He further promised to 'engage one million $\mathrm{N}$-power graduates and to skill up 10 million Nigerians through agriculture and industrialisation' (Oladesu 2019, p.7).

PDP candidate Atiku, on the other hand, sought to boost investment in the country's oil sector if he became president in 2019. In a document titled, Let's Get Nigeria Working Again, Atiku promised to privatise the nation's four refineries, partially privatise the Nigerian National Petroleum Corporation, restructure the economy, and increase the country's Gross Domestic Product to $\$ 900 \mathrm{bn}$ by 2025. The PDP candidate promised to attract investment that 'would create a minimum of 2.5 million jobs annually and lift at least 50 million people out of extreme poverty by 2025' (Ajaja 2018, p.5). Atiku assured Nigerians that he would be a better economic manager than Buhari, citing that when he chaired the National Economic Council the Obasanjo administration gave the country its highest and most consistent gross domestic product (GDP) growth of over six percent per annum.

Overall, the manifestos of the two candidates were neither novel nor captivating. The campaigns also focused on geopolitics, devoting attention to creating a winning geopolitical formula. Two leading party leaders from the same presidency, Babatunde Fashola (Works and Housing Minister) and Boss Mustapha (Secretary to the Government of the Federation (SGF)) were both said to have promised the post-2019 presidency to the South West and South East. Buying into this narrative and sensing the enthusiasm of the southern region to succeed the incumbent in 2023, the PDP presidential candidate, during his pre-convention vote-seeking, also committed himself to serving for just four years, thus clearing the way for the Igbo to actualise their presidential ambitions as early as 2023 . He did promise, through his media handlers, that he was out for a single term, and by inference that either the South West or South East could have their turn at the end of his first term in 2023. However, his post-convention campaign was silent on that sentiment. But in a zone where separatist sentiment was quite fevered in recent times, Atiku's restructuring rhetoric played equally well with a section of the South East's political elite (Eriye 2018).

\section{FAKE NEWS, DEFECTIONS AND CACOPHONOUS HUSTINGS AS DIVERSIONARY STRATEGIES}

As Nigeria prepared for the elections, the proliferation of fake news through Facebook and its WhatsApp messaging platform exacerbated tense ethnic, 
political, religious and social divides. Many of these were created by politicians, and/or ignorantly or deliberately by the media, interest groups. The problem became so acute that the government warned that misinformation could be the biggest threat to credible elections (Wexler 2019). Throughout the campaign, there was a high level of negative speeches and frivolous debates indicating a mudslinging race that served only to distract the voters. Through Whatsapp, Facebook and Twitter, people shared propaganda videos, made-up quotes, and fabricated articles. The incumbent, President Muhammadu Buhari, and his main rival, Alhaji Atiku Abubakar, became the target of online videos containing shady or ambiguous information. As the campaign heated up, 16 media outlets formed a coalition, CrossCheck Nigeria, in a fact-checking initiative to investigate doubtful election claims circulating online. Two of these issues are presented here.

Given that Nigeria's historical, religious and ethnic fault-lines are often deployed during election seasons, false stories and rumours became more prominent with a view to swaying votes (Kazeem 2018, p. 4). Political parties and candidates did not stop at wooing voters, they also attempted to pull down the opposition. Fake news became a handy tool in achieving their mission (Adetayo 2019). For instance, one of the most frequently accessed rumours spread online was that President Buhari had died in a London hospital, having spent months receiving treatment in 2017. Supporters of pro-Biafran separatist leader, Nnamdi Kanu, had also claimed that Buhari was replaced by a lookalike from Sudan. This became a talking point in several newspaper columns, with commentators speculating on the scientific possibilities of cloning a human being. Opposition politicians sought to capitalise on the rumours for political gain (Akinwotu 2019). As absurd and unthinkable as it sounds, the planted 'clone' or 'double' narrative achieved its objective and dominated media space, occupied intellectual discourse and ensnared civil society organisations. As expected, the presidency devoted precious time to defending this absurdity.

Another incident involved a Special Adviser on Social Media to President Buhari - Lauretta Onochie, who posted a video on Twitter which showed his supporters at a large rally when in reality the images were from a religious gathering the previous year. She also posted a photograph of a major road construction, citing it as an example of the president's public works. She was later forced to issue an apology after discovering that the road was actually in Rwanda, saying: 'My big mistake, apologies to all, friends and wailers alike. It won't happen again' (Anderson 2019, p. 34). Months later, it did so in a tweet that accused Alhaji Abubakar of sharing food and money during his campaign. It was accompanied by a photograph of food packs with money attached and a caption saying: 'Keep them in poverty, then give them handouts. Atiku in Sokoto yesterday' (ibid.). 
Stories that CrossCheck Nigeria discredited included allegations that the first lady wanted Nigerians to vote against her husband, as well as a suggestion that US President Donald Trump endorsed opposition candidate Atiku Abubakar. Such allegations usually appeared on social media and were sometimes published by news websites (VOA 2019). False reports spread on social media so fast and so frequently that some of those who were the subjects simply had to laugh it off. Indeed, the spread of disinformation was used to promote hate speech and stereotypes. A few months before the election, the cacophony of fake news distracted citizens' attention from the real issues affecting them - widespread discontent over unemployment, insecurity and poverty, the high cost of living, and perceived marginalisation across the country.

Another distraction during the election was the number of personalities defecting to and from the two main parties. Because political parties in Nigeria lack ideologies and explicit messages that distinguish them from one another (Barnes 2018), politicians merely view political parties from the lens of temporary platforms to contest and win elections, rather than ideological platforms where they can present a responsible opposition or responsive government. Thus, months before the 2019 general elections, the two dominant parties witnessed major and unprecedented defections. Between 2017 and early 2019, there were mass defections from the ruling All Progressives Congress to the People's Democratic Party involving members of the National Assembly and prominent members in some states. The excuses for these mass defections were in most cases identical to those that precipitated PDP defection to the APC in 2014 when the struggle to wrest power from the then ruling PDP was considered 'imperative' by some of the defectors. The strategy had weakened the PDP, leading to its defeat in the 2015 elections. The defectors, who included key figures of Buhari's APC, were largely motivated by their personal ambitions and interests rather than any higher ideal.

Ironically, and for the first time in decades, both ethnic and religious considerations that would have dominated the electoral campaign were conspicuously absent. Ordinarily, 'there is an unwritten rule between the two major parties that the presidency should alternate every eight years' (Campbell 2018, p.3) between the predominantly Muslim north and the predominantly Christian south. In the 2019 presidential elections, the two frontline presidential candidates shared the same ethnic and religious affinities - Muslim and Fulani from the North.

Nigerian's Independent National Electoral Commission (INEC) had 91 parties on its register in 2019, 73 of which took part in the general elections. Most of the small parties failed to convince the electorate that they were competing seriously in the elections (Nigeria Civil Society Situation Room 2019) while the two main parties, the ACP and PDP, embarked on a blame-game electoral outing despite their early commitment to an issue-based campaign. 


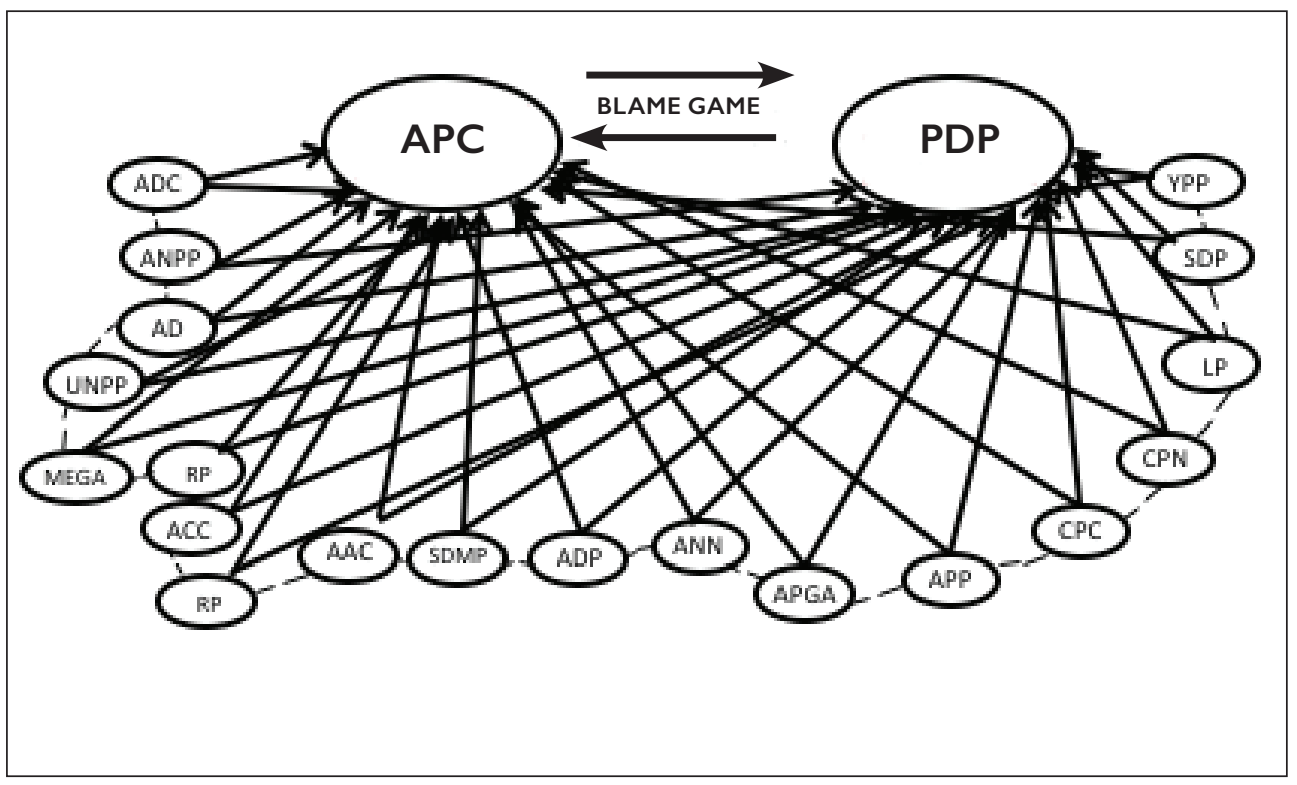

Source: Mike Omilusi 2019

Figure 1: 2019 Campaign Blame Game

Every public discourse involving their spokespersons was reduced to trading words on the mess one party had caused for sixteen years and the failure of the other party to change the narrative as promised

In a similar vein, the parties on the fringes focused their campaigns on getting the voters to reject the APC and PDP on the grounds that both had failed the country in power. Catch phrases used at rallies and in the electronic media included: 'We need a third force to liberate Nigeria from the present mess' and 'APC and PDP have failed Nigerians'. Despite the rhetoric, these minor parties were weak. Their multiplicity worked against them because they could not present a united front.

\section{KEY RESEARCH FINDINGS}

In this section, basic findings from the survey are graphically presented to show the perception of Nigerians concerning the 2019 general elections in relation to the dynamics, efficacy or otherwise of the two major political parties' campaign communication and how respondents feel about policy implementation after election. The questions are phrased as diagram titles for clarity. 


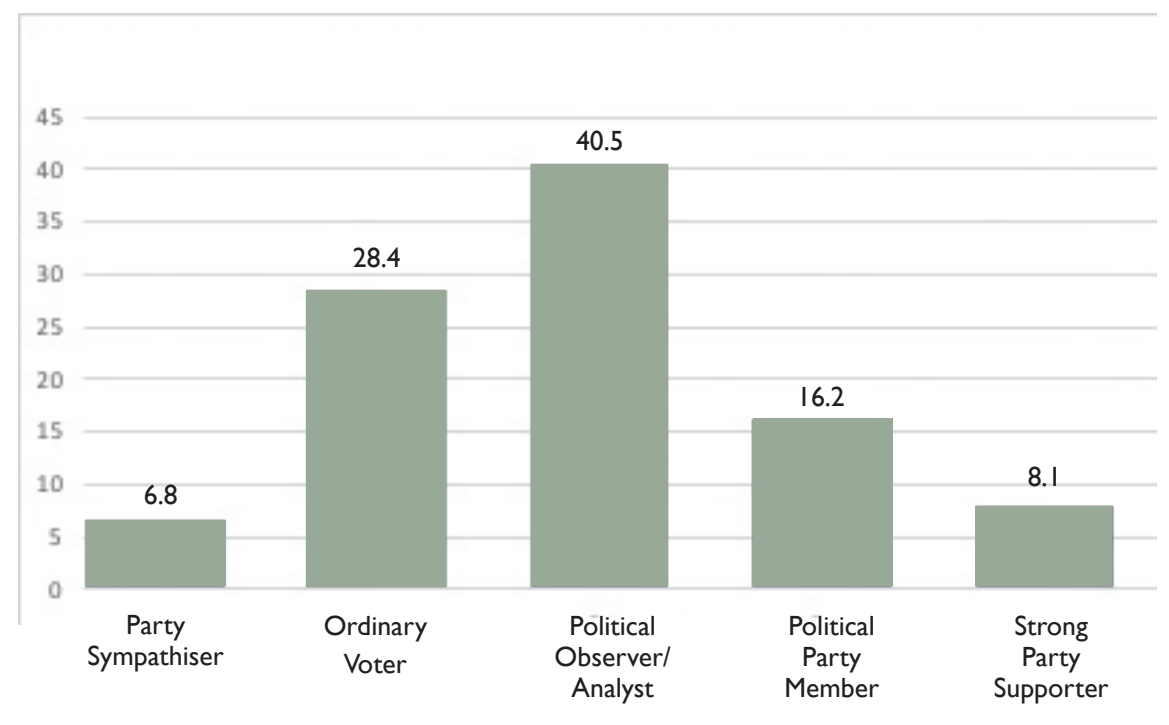

Figure 2: Political categorisation of respondents

Figure 2 above portrays categories into which individuals are likely to fall. About 6 percent of the respondents categorise themselves as mere party sympathisers, about 28 percent as ordinary voters, about 40 percent as political observers/ analysts, about 16 percent as politicians or party members, and about 8 percent as strong party supporters. It is obvious from the statistics that there are more political observers than any other category.

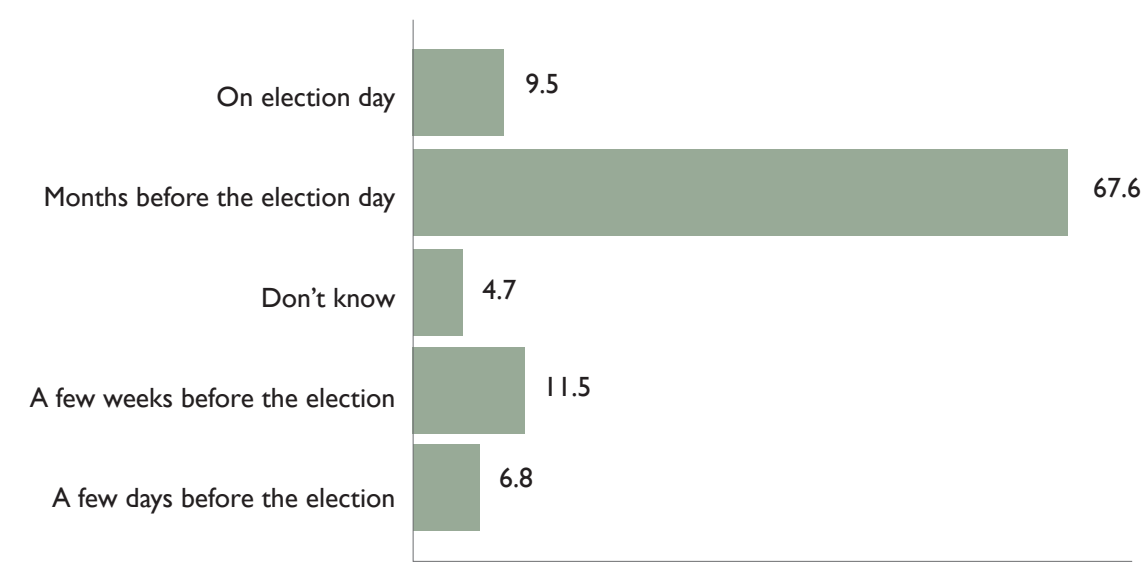

Figure 3: When respondents decided to vote for a party/candidate 
Figure 3 above indicates when people decided to vote for or support any party. About 6 percent of the respondents revealed that they decided to vote a few days before the election day, about 11 percent that they decided a few weeks before the election, about 67 percent revealed that they made up their minds on parties/ candidate to align with months before the election, and about 9 percent revealed that they took the decision on election day.

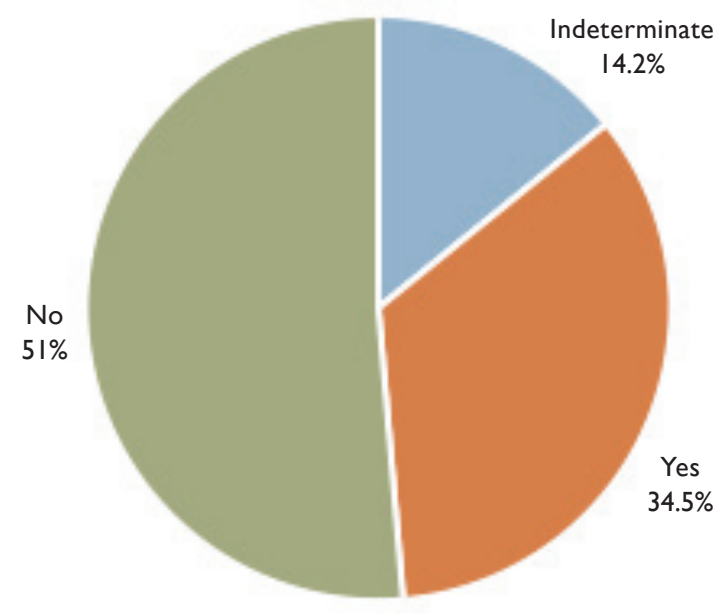

Figure 4: Extent to which respondents were influenced to vote for candidates based on issues discussed at rallies and through the media

Most people did not know whom to vote for based on the limited information they had on the available political parties. Some were undecided until near to the election while others supported the candidate most favoured by the media. Figure 4 above shows that about 34 percent of the respondents were influenced to vote based on issues discussed at rallies and through the media, whereas about 51 percent revealed that they were not influenced by political rallies or media campaigns.

There are many ways through which political parties and candidates reach their target audience. Figure 5 below shows the five major media and the extent to which they serve as information server for people. 


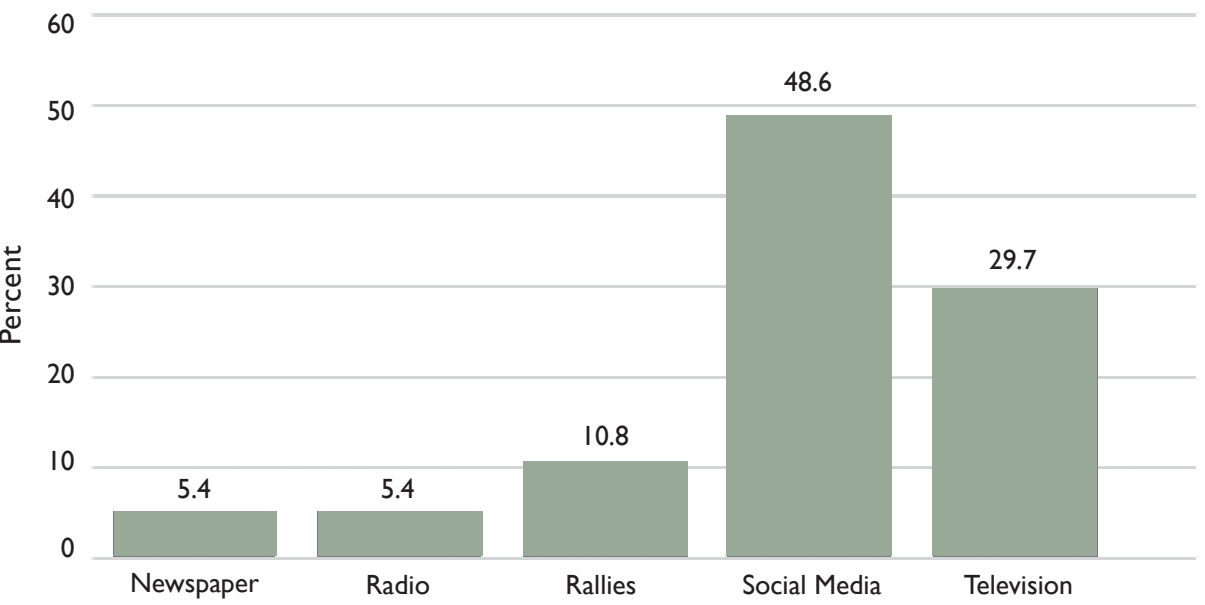

Figure 5: Medium through which the presidential campaign was monitored

About 5 percent of the respondents revealed that they monitored the presidential campaign through newspapers, 5 percent through the radio, 10 percent through campaign rallies, 48 percent through social media such Facebook, Twitter and Google connect, and 29 percent through television (including cable services). People make more use of social media as it is faster and readily accessible. Likewise, most cable TV stations are expanding their services and making their subscriptions more accessible, thereby gaining a larger audience more cheaply and thus making it second in usage, as Figure 5 above reveals.

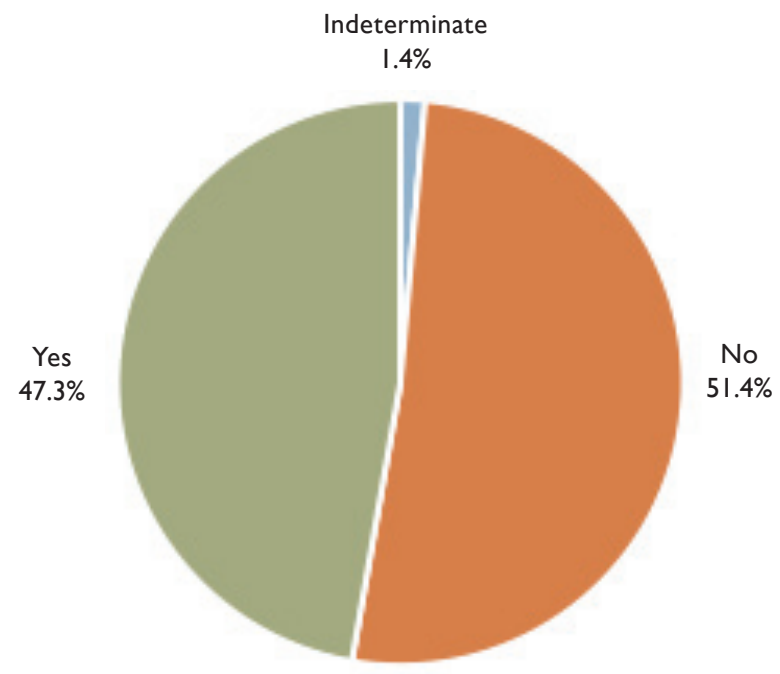

Figure 6: Level of contact by candidates or canvassers for a political party 
Some candidates do visit prospective voters in their communities, persuading them through their manifestos or by gifts. House-to-house campaigns, meeting people one-on-one are considered a sign of humility and respect. Figure 6 above shows that about 47 percent of the respondents were visited by party members seeking their votes, while about 51 percent said they had no such experience.

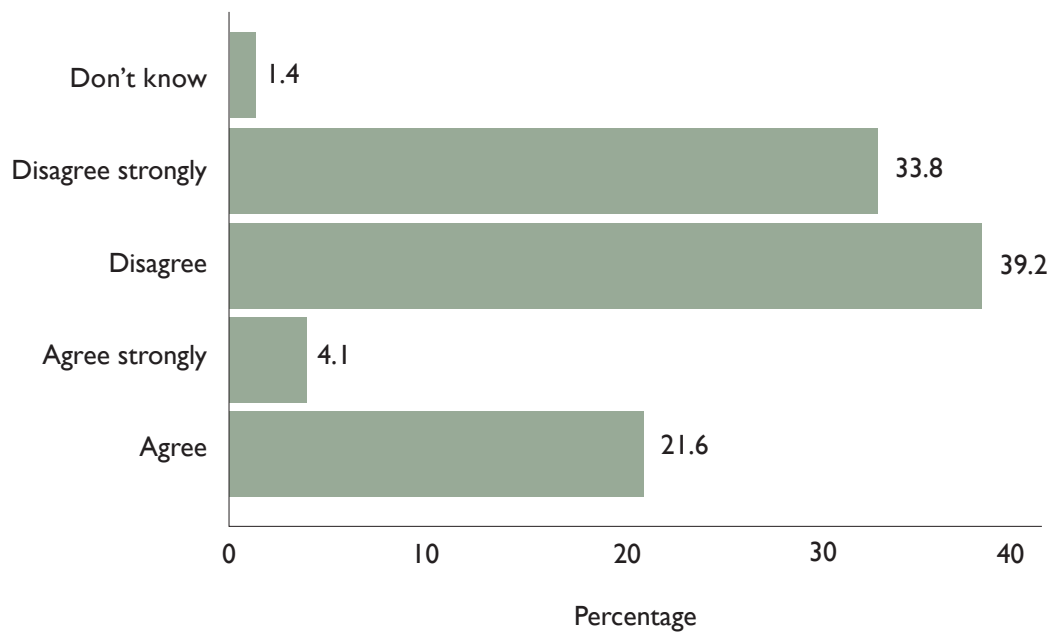

Figure 7: Whether democracy in Nigeria delivers development and bridges the gap between government and citizens

Figure 7 above shows the perception of Nigerians concerning the effectiveness of democratic governance in delivering development, and whether democracy bridges the gap between government and the citizens. Curiously, about 73 percent of the respondents see democracy in Nigeria as a total failure; however, 25 percent still see democracy in Nigeria delivering development and bridging the gap between government and the citizens. As one of the respondents observed:

Ordinarily one would expect that our votes should influence electoral outcomes and ultimately bring about the desired change in the polity. However, every form of participation in the electioneering seems to be alienating the people further from governance deliverables and decision-making process. Indeed, the most ardent believers in this democracy today are getting frustrated with the pitiable living the system has guaranteed them.

(Personal communication, April 23, 2019) 


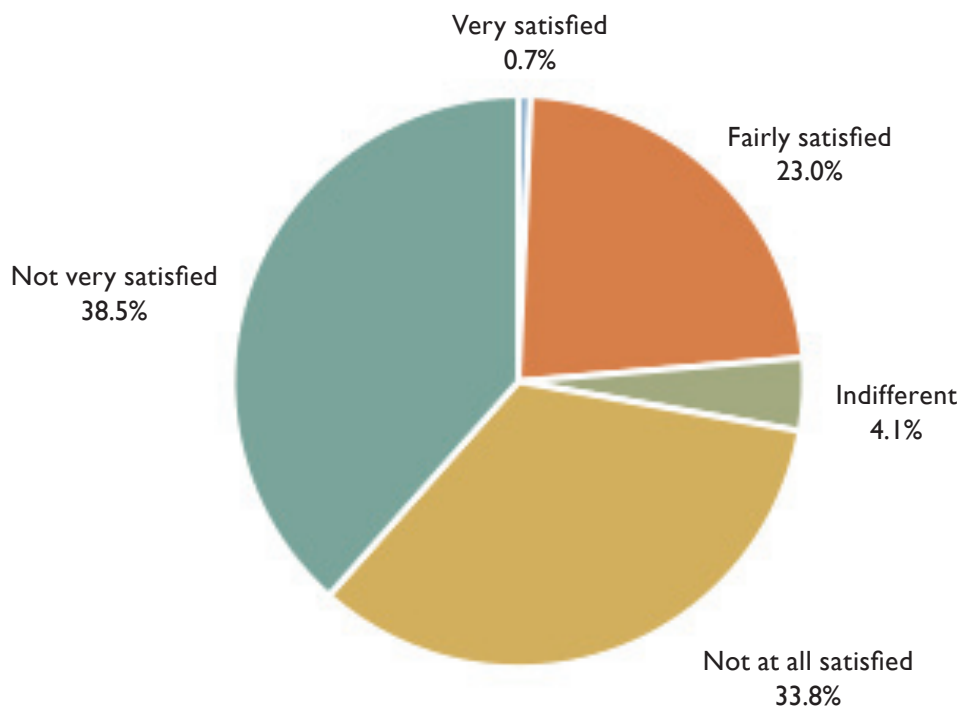

Figure 8: Level of satisfaction with the way successive governments have run Nigeria since 1999

Nigeria has faced ever-increasing economic and political challenges since the emergence of democracy in 1999, and Figure 8 above depicts the level of satisfaction towards government. The figure indicates that 23 percent of the respondents are fairly satisfied with the way and manner successive governments have been running the affairs of the country, 33 percent are not at all satisfied, 38 percent are not very satisfied, and only a minute segment of the population $(0.7$ percent) admitted satisfaction regarding the political management of the country. According to a respondent (Personal communication, 4 May 2019):

Successive administrations have continually failed us. That is why, apart from freedom of expression, we cannot specifically identify other dividends of democracy in the country. Therefore, Nigerian politicians, particularly those at the helms of affairs, should commence rebuilding trust with the ordinary voters through effective communication and service delivery. 


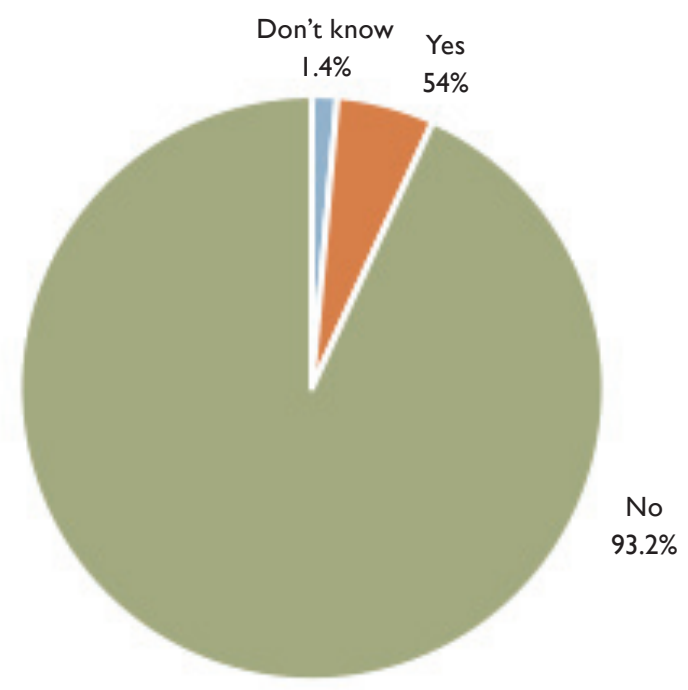

Figure 9: Respondents' perception of social contract during the presidential campaign

Figure 9 above depicts the responses regarding any form of social contract with candidates or political parties during the presidential campaign, particularly if an agreement was reached with the people on the basis of programmes-for-votes. The statistics revealed that about 93 percent of the respondents did not believe there was any concrete pact with candidates or political parties. Only 5 percent of the respondents believed such took place during the presidential campaign.

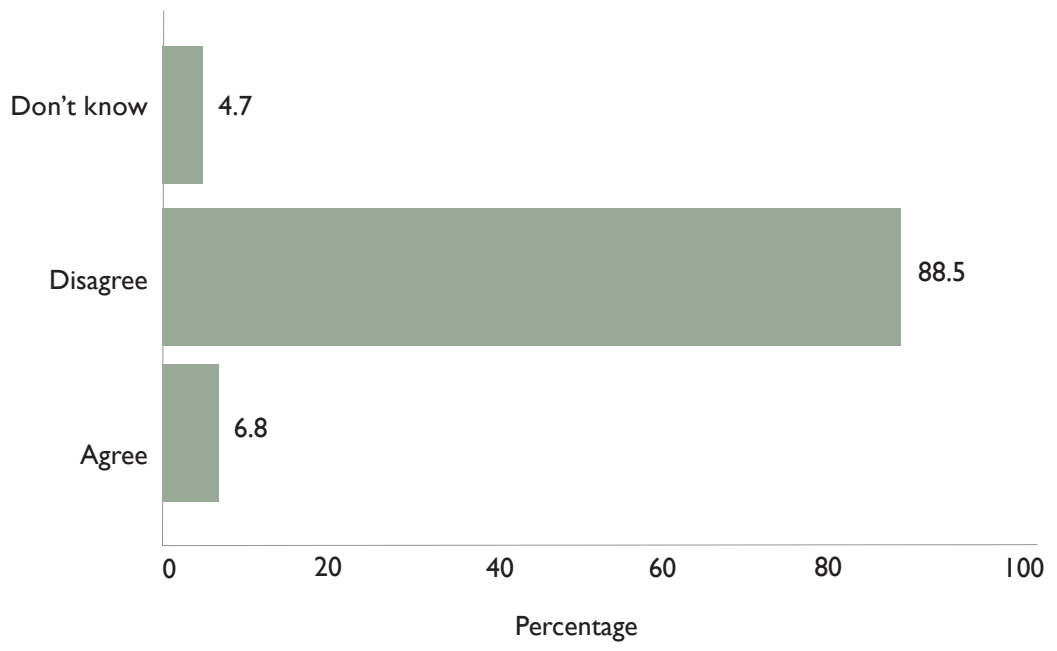

Figure 10: Rating politicians' trustworthiness in Nigeria 
As shown in Figure 10, the majority of the respondents (over 88 percent) do not consider Nigerian politicians to be trustworthy. Also, drawing from in-depth interviews and focus group discussions, it appears that citizen trust in Nigerian politicians in particular and all levels of government in general, is fast eroding:

How does one trust a political class that has not hidden its disdain for the common men and women? It is a pathetic case of less than one percent of the population making life miserable for the rest of us. We bear the brunt of the struggle for power without commensurate obligations after election. They are totally disconnected from the needs of their constituents.

(Personal communication, 23 April, 2019)

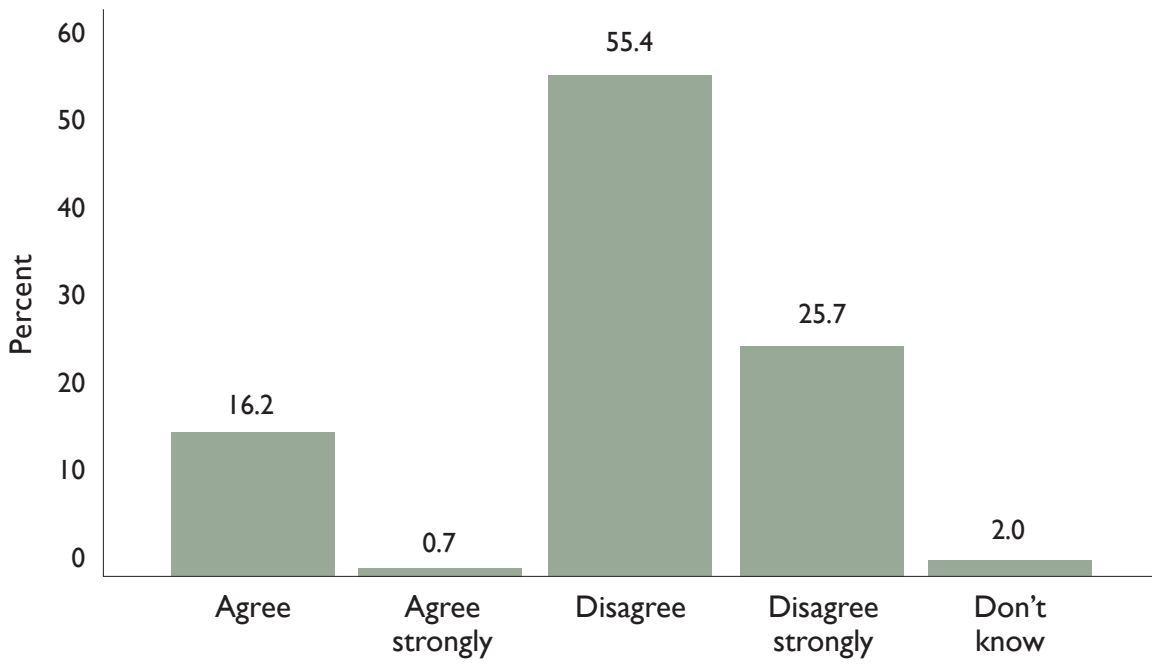

Figure 11: Whether the APC and PDP candidates addressed issues affecting Nigerians

Figure 11 above reveals that 80 percent of the respondents strongly agree that both the APC and the PDP failed to address issues affecting Nigerians. Conversely, very few believe that both parties did address issues affecting Nigerians. A respondent who claimed to have monitored the electioneering campaign through electronic and print media commented that:

There is little or no difference between the two dominant political parties. Their campaigns were largely rhetoric about good governance 
and provision of social amenities which we have ceaselessly heard from political leaders since independence without fulfilment. I am beginning to suspect that voters are also fed up with such monotonous promises.

(Personal communication, 23 April 2019)

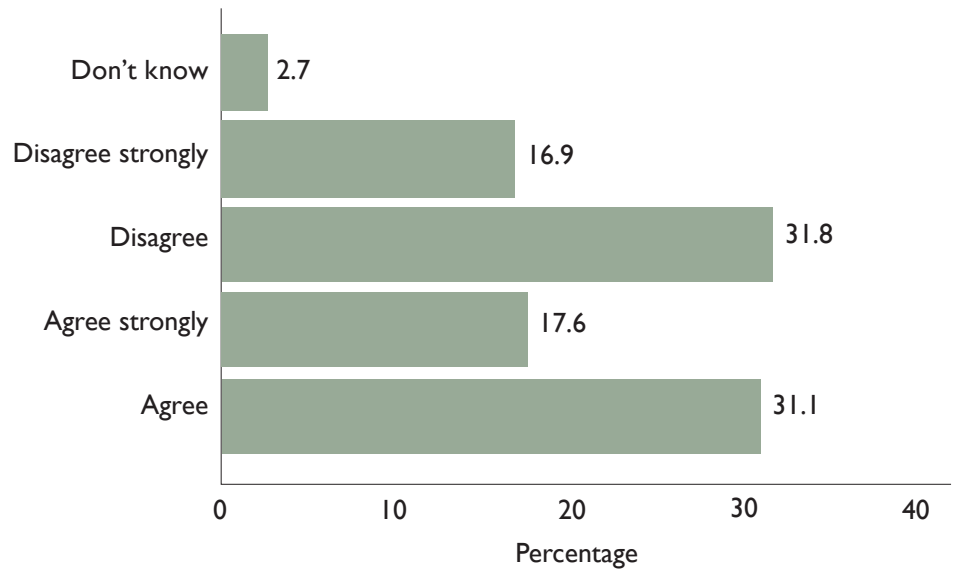

Figure 12: Whether the presidential election debate was a worthwhile exercise

Figure 12 above depicted the responses of people regarding the level of their perception of the 2019 presidential election debate. There is equal ground regarding whether the presidential election debate was worthwhile, as 48 percent of the respondents considered it to be a worthwhile exercise, as opposed to 48 percent who considered it an irrelevant exercise.

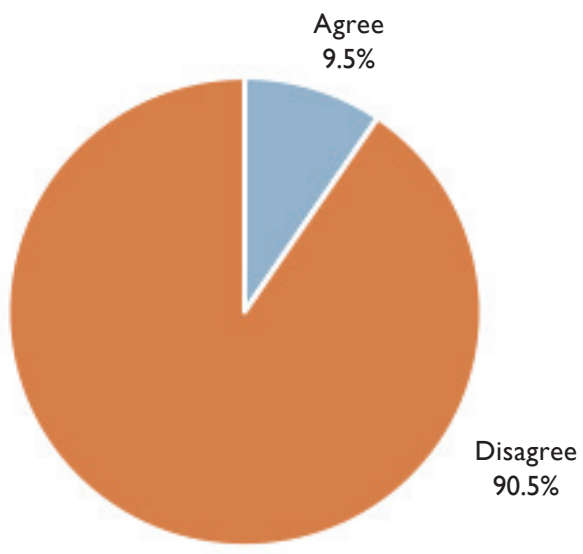

Figure 13: Whether politicians/political parties implement their manifestos after election 
Figure 13 above shows that 90 percent of the respondents agreed that politicians and political parties usually fail to implement their manifestos after the election; this is strong evidence of eroding trust in Nigeria's political system.

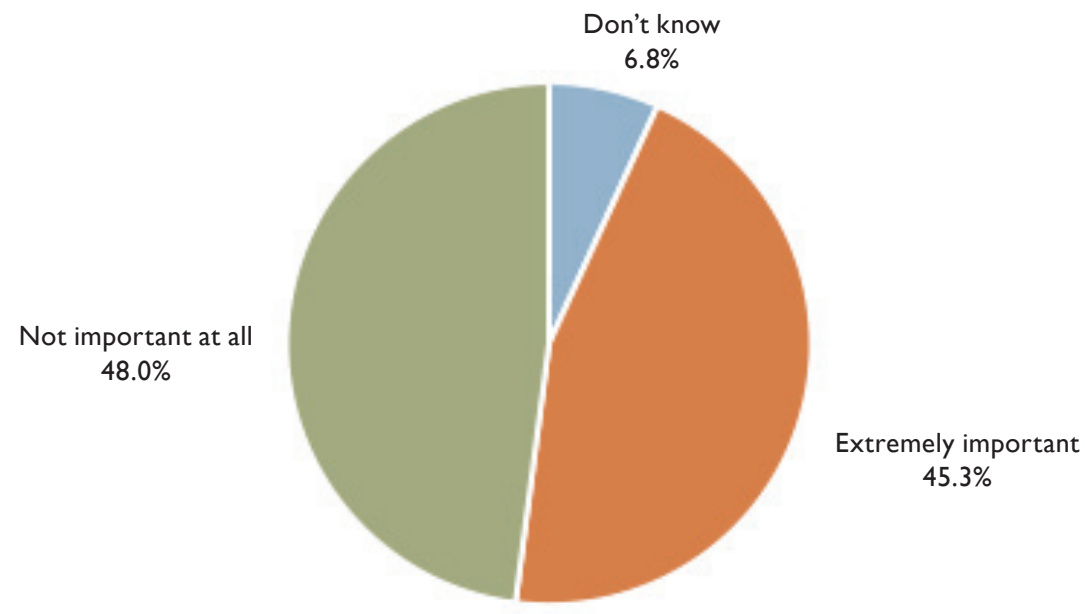

Figure 14: Rating the importance of campaign manifestos in Nigerian elections

The information presented in Figure 14 above buttresses the argument so far. About 48 percent of the respondents opined that campaign manifestoes are not at all important in Nigerian elections, whereas 45 percent considered campaign manifestos extremely important.

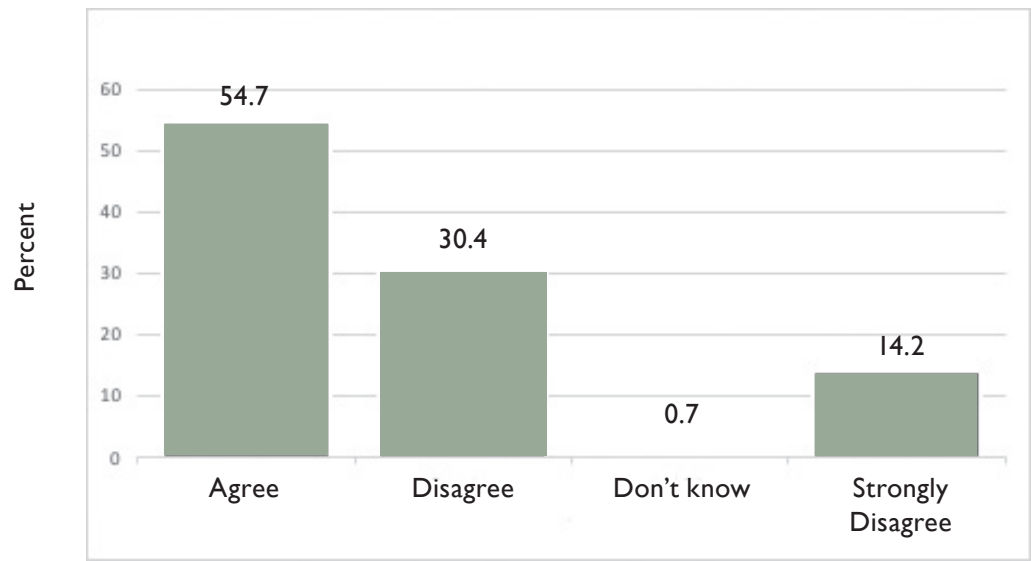

Figure 15: Whether there is any point voting for a party with no chance of being in government 
Figure 15 above shows the response to voting for parties with a very low chance of winning. About 54 percent of the respondents are of the opinion that there is no point voting for a party that has no chance of being in government or winning the election, whereas about 44 percent totally rejected this view as they believe that even a less popular party may perform better than those that are more popular.

\section{RECOMMENDATIONS: SOCIAL CONTRACT, ELECTORAL REFORM AND DEMOCRATIC ACCOUTABILITY}

\section{Social Contract}

The social contract between voters and their elected representatives has long remained one of the foundations of democratic institutions (Transparency International 2019). The social contract is a fundamental principle of legitimising governmental organisation, as it provides a starting point for a rational explanation of the origin of the state. The idea is that the authority of government over supposed subjects or citizens derives originally from an agreement between ruler and ruled in which the former agrees to provide advantages such as peace, security and order in return for obedience from the latter.

In a viable democracy, government statements and actions must have some degree of trust from the citizens as a prerequisite for an effective social contract (Gaskarth 2017). In other words, the contractual agreement that obtains between the citizenry and a constituted authority presupposes that elections should afford citizens the opportunity to periodically bargain with public office holders and decide whether to renew their mandate or vote an irresponsible government out of power. This is what a credible election can guarantee Nigerians and thus teach politicians to hold sacrosanct the principle of social contract in a democratic society. Citizens should continually hold public office holders and government institutions accountable, in order to prevent new governance and security challenges.

\section{Electoral Reform}

Generally undertaken to enhance the electoral process, electoral reforms also advance the electoral rights of citizens by operationalising 'key principles such as impartiality, inclusiveness, transparency, integrity and accuracy' (IDEA 2014, p. 16). To bring elections in line with regional and international standards for democratic elections in Nigeria, a number of fundamental challenges must be surmounted. These include weak transparency requirements for the publication of 
results; absence of provisions empowering INEC to sanction campaign violations; manual voting and collation of results; insufficient campaign finance regulations; and the inability of voters and civil society organisations to file petitions against the results.

Thus, it is strongly recommended that the Electoral Act Amendment Bill be passed into law. Among other salient inputs, the bill prescribes the announcement and pasting of results at each polling unit, and the electronic transmission of results from the polling unit directly to the headquarters of the Independent National Electoral Commission. The bill outlaws the use of incident forms in polling units where the Smart Card Reader does not work. In the new Section 53 (2), it prescribes that where the final figure is more than the number of accredited voters at any polling unit, the results are automatically cancelled. It also prescribes the digital storage/archiving of election results at INEC headquarters (The Guardian, 2019).

More important to this study is that sections 30, 44 and 99 of the amended bill are targeted at improving the electoral process. Section 99 states that candidates and parties can commence their campaigns 150 days (or five months) before the polls. In contrast, the current act stipulates 90 days for campaigns. Given the fact that it is important for citizens to have adequate time to interrogate those to whom they are delegating their own power to govern, this section is fundamental to the electoral reform. With 774 local government areas, 36 states and the Federal Capital Territory, it enables candidates to cover a lot of ground and present their manifestos to the electorate (The Guardian, 2019).

\section{Democratic Accountability}

The question of democratic accountability is critical as government's role in the electoral process and governance comes to the fore. In order to ensure accountability and governance in the system, representative democracy is widely acknowledged as a system of government whereby elected representatives act on behalf of the citizens. The task of holding leaders to account is one of the logics behind the voting power of the masses and relies on the trust between the electorate and elected leaders. There are several forms of accountability:

- vertical accountability, which allows citizens to choose their leaders through free, fair, transparent, regular, and meaningful elections, which happen when there is an acceptable level of political rights and civil liberties;

- horizontal accountability, the ability of government institutions to check abuses by other branches of government, a system in which government institutions are independent and no agency or branch becomes too powerful in relation to the others; and lastly 
- personal accountability, an individual's responsibility and commitment to uphold high standards.

The underlying proposition is that democratic mechanisms should enhance citizens' capacity to hold public officials accountable for their actions while government officials should act upon citizens' demands and preferences. Despite their shortcomings, political parties and elected representatives in Africa have dual roles to play in the accountability landscape (IDEA 2007). As account holders, they can be democratic instruments holding governments to account. Simultaneously, they may respond to the demands of their voters through the electoral cycle as agents of accountability. While in power, therefore, parties and public office holders should 'account for the manner in which they allocate and spend public funds, make public policy and take decisions which affect the people in whose name they govern' (Chirwa \& Nijzink 2012, p. 63). Ordinarily, governments cannot respond effectively to the needs of the people without accountability (ibid.) or set national agendas that address current and important challenges because accountability in government ensures equality, fairness and equity in public decision-making (Behn 2001). As in advanced democracies, democracy in Nigeria can only thrive and be sustained by accountability. Therefore, the essence of public accountability must be held sacrosanct by all persons in positions of public leadership and citizens alike.

\section{CONCLUSION}

Core processes of democratic governance such as elections and referendums often become dangerously outmoded, especially when they are not strengthened by pragmatic forms of citizens' participation (Van Reybrouck 2016). This study emphasises that a more crucial, liberal and inclusive form of democracy can be engendered by structured consultation with the mass of the people during and after elections. Considering the imperative of having elected public representatives accountable to the electorate on issues of concern or dissatisfaction (Brinkerhoff 2001, p. 95), this study contends that moving from ritualistic formalities to more strategic approaches capable of fundamentally addressing policy issues arising from campaign promises is crucial to democratic accountability and good governance.

However, debate continues to rage over those basic elements that shape voter behaviour or determine electoral outcomes across the globe. The study affirms that every voter has the right to scrutinise the manifestos of candidates as well as their campaign promises, their requisite experience, and their track record of achievements, with a view to taking an informed position on franchise. The 2019 elections, as revealed in this study, did not reflect what the social contract 
stands for - 'the implicit, mutual bargaining over what citizens expect from the state, and what the state can legitimately demand of citizens in return' (World Bank 2019, p.8) - as electioneering campaigns did not provide the space for social contract bargaining.

\section{REFERENCES}

Adetayo, O 2019, 'Politicians, fake news and the 2019 elections', The Punch, 5 March. Ajaja, T 2018, '2019 campaigns: Between beautiful manifestos and Nigeria's 'long' journey to greatness', The Punch, 24 November.

Akinwotu, E 2019, 'Whose Truth? Disinformation and misinformation online in Nigeria', West Africa Insight, vol. 7, no. 1.

Anderson, P 2019,'Tackling Fake News: The Case of Nigeria', https://www.ispionline. it/sites/default/files/pubblicazioni/ispi_commentary_anderson_23.05.2019. pdf

Aragonès, E, Postlewaite, A \& Palfrey, T 2007, 'Political Reputations and Campaign Promises', Journal of the European Economic Association, vol. 5, no. 4, pp. $846-884$.

Ayee, J 2011, 'Manifestos and elections in Ghana's Fourth Republic', South African Journal of International Affairs, vol. 18, no. 3, pp. 367-384.

Barnes, S 2018, 'Defections, Decamping and Cross-Carpeting: The Challenges Facing Nigerian Political Parties Ahead of the 2019 General Elections', https://www. democracyspeaks.org/blog/defections-decamping-and-cross-carpetingchallenges-facing-nigerian-political-parties-ahead

Behn, RD 2001, Rethinking Democratic Accountability, Brookings Institution Press, Washington, DC.

Bogdanor, V 2015, 'General election: Do party manifestos still matter?', Financial Times, 15 April.

Bonilla, T 2017, 'The Strategy of Campaign Promises,' https://www.semanticscholar. org/paper/The-Strategy-of-Campaign-Promises-Bonilla/856f6e8fc53924b79 e56470232139038f4680d2d

Brinkerhoff, D 2001, Taking account of accountability: a conceptual overview and strategic options, United States Agency for International Development (USAID), Washington DC.

Brouard, S, Grossman, E, Guinaudeau, I, Persico, S, \& Froio, C, 2018, 'Do Party Manifestos Matter in Policy-Making? Capacities, Incentives and Outcomes of Electoral Programmes in France', Political Studies, vol. 66, no. 4, pp. 903-921. https://doi.org/10.1177/0032321717745433

Campbell, J 2011, Elections and Political Parties in Nigeria. Available at: https://www. cfr.org/blog/elections-and-political-parties-nigeria 
Campbell, J 2018, The Stage Is Set for Nigeria's February 2019 Presidential Election. Available at: https://www.cfr.org/blog/stage-set-nigerias-february-2019presidential-election

Chirwa, DM \& Nijzink, L 2012, Accountable Government in Africa: Perspectives from public law and political studies, United Nations University Press, Tokyo.

CHPI 2017, 'What do the main party manifestos say about the NHS?'Election Briefing Note June. Available at: https://chpi.org.uk/wp-content/uploads/2017/06/ CHPI-2017-Manifesto-comparison.pdf

Devermont, J 2019, What to Watch in Sub-Saharan Africa in 2019. Available at: https:// www.csis.org/analysis/what-watch-sub-saharan-africa-2019

Eder, N, Jenny, M \& Müller WC 2017, 'Manifesto functions: How party candidates view and use their party's central policy document', Electoral Studies, vol. 45, pp. 75-87.

Edgell, AB, Mechkova,V, Altman, D, Bernhard, M \& Lindberg, SI 2017, ‘When and where do elections matter? A global test of the democratization by elections hypothesis, 1900-2010', Democratization, vol. 25, no. 3, pp. 1-23.

Elmelund-Præstekær, C 2010, 'Beyond American negativity: Toward a general understanding of the determinants of negative campaigning', European Political Science Review, vol. 2, no. 1, pp. 137-156.

Eriye, F 2018, 'Atiku's Southeast quandary', The Nation, 1 December.

Ferraz, C \& Finan, F 2015, ‘Exposing Corrupt Politicians: The Effects of Brazil's Publicly Released Audits of Electoral Outcomes'. In Improving Electoral Participation: Evidence from Randomised Evaluations, https://www. povertyactionlab.org/sites/default/files/event/Improving\%20Electoral\%20 Participation\%20Booklet_Full.pdf

Franklin, B 1994, Packaging Politics, Edward Arnold, London.

Gaskarth, J 2017, 'The emerging social contract in Asia', Observer Research Foundation, 20 February, https://www.orfonline.org/expert-speak/emerging-socialcontract-asia/

Grossman, GM \& Helpman, E 1996, 'Electoral Competition and Special Interest Politics', Review of Economic Studies, vol. 63, no. 2, pp. 265-286.

Hampshire, J 2016, 'The Cost of Broken Promises or How Policy Failure Can Help Win Elections - Immigration and the 2015 UK General Election', Revue Française de Civilisation Britannique [Online], XX-3 | 2015, Online since 01 December 2015, connection on 30 September 2016. http://rfcb.revues.org/560; DOI : $10.4000 / \mathrm{rfcb} .560$

Hanusch M, Keefer, P \&Vlaicu, R 2016, 'Vote Buying or Campaign Promises? Electoral Strategies When Party Credibility Is Limited', IDB Working Paper Series $\mathrm{N}^{\circ}$ IDB-WP-691

Hassan, I 2018, 'Nigeria's 2019 elections: The preparations, people and prospects'. Available at: https://africanarguments.org/2018/03/26/nigeria-elections2019-politics-and-prospects/ 
Heywood, A 2000, Key Concepts in Politics, Macmillan, London.

Heywood, A 2007, Politics,3rd ed., Palgrave Macmillan, Basingstoke.

IDEA 2007, 'Political Partiesin Africa: Challenges for Sustained Multiparty Democracy'.

Available at: http://web.msu.ac.zw/elearning/material/1257171344Africa_ report_inlay_final.pdf

IDEA 2010, 'Democratic Accountability and Service Delivery-A Desk Review' https://www.ids.ac.uk/files/dmfile/IDEADASDDeskreviewv10.pdf

IDEA 2014, 'Electoral Law Reform in Africa: Insights into the Role of EMBs and Approaches to Engagement'. Available at: https://www.idea.int/sites/default/ files/publications/electoral-law-reform-in-africa.pdf

Jansen, EH, Scheltens, J, Molleda, JV \& van der Staak, S 2016, The Policy Positioning Tool for Political Parties: A Facilitator's Guide, Available at: https://nimd.org/ wp-content/uploads/2016/03/IDEA-NIMD_ProDemos_PPTPP_total_def.pdf

Kazeem, Y 2018, 'Nigerian media houses are forming a coalition to combat fake news ahead of next year's elections', Quartz Africa, 29 November.

Matlosa, K 2007, 'Political Parties in Southern Africa: The State of Parties and their Role in Democratization', Report prepared for the International Institute for Democracy and Electoral Assistance (International IDEA) as part of its global Programme on Research and Dialogue with Political Parties.

Maphunye, KJ 2016 Are Africa's elections underscored by accountability and the social contract? Available at: http://uir.unisa.ac.za/bitstream/ handle/10500/21001/Prof.\%20Kealeboga\%20J.\%20Maphunye $\% 20$ Inaugural $\% 20$ lecture.pdf?sequence $=1 \&$ isAllowed $=\mathrm{y}$

McLachlan, H 2017, 'Making big manifesto promises is unethical - and can be disastrous for politicians', The Conversation, 6 June.

Mubanga, L 2016, 'Political party manifestos in elections', Zambia Daily Mail,14 June.

Mumbere, D 2018, 'Nigeria: Buhari's anti- corruption agenda vs Atiku's economic growth plans', africanews, 19 November.

Nichter, S 2008, 'Vote buying or turnout buying? Machine politics and the secret ballot', American Political Science Review, vol.102, no. 1, pp. 19-31.

Nigeria Civil Society Situation Room 2019, Report of Nigeria's 2019 General Elections, http://www.placng.org/situation_room/sr/wp-content/uploads/2019/07/ Report-on-Nigerias-2019-General-Elections.pdf

Norris, P \& Kennedy, J 2001, Do Campaign Communications Matter for Civic Engagement? American Elections from Eisenhower to G.W. Bush, Routledge, London.

Oladesu, E 2019, 'Lessons of 2019 elections', The Nation, 27 March.

Owen, D 2017, 'New Media and Political Campaigns'. In K Kenski\& KH Jamieson (eds.) The Oxford Handbook of Political Communication, Oxford University Press, Oxford. 
Petry, F \& Collette, B 2009, 'Measuring How Political Parties Keep Their Promises: A Positive Perspective from Political Science' In Do they walk like they talk, pp. 65-80.

Rölle, D 2002, 'NichtsGenaues Weiss Man Nicht!?' In: KölnerZeitschriftfürSoziologie und Sozialpsychologie, vol. 54, no. 2, pp. 264-280.

Shaw, JS, 2002, 'Public choice theory', In DR Henderson \& L Summers (eds.) The Concise Encyclopedia of Economics, Liberty Fund, Carmel, Ind.

Signé, L 2018, 'Accountability and demand for democracy drive leadership changes in Africa', https://www.brookings.edu/opinions/accountability-anddemand-for-democracy-drive-leadership-changes-in-africa/

Svetlik, M 2018, 'Elections to Watch in 2019', International Foundation for Electoral Systems. Available at: https://www.ifes.org/news/elections-watch-2019

The Guardian 2019, 'Buhari, sign Electoral Amendment Bill now', Editorial, 26 April. Thomson, $\mathrm{R}$ et al. 2012, 'The program-to-policy linkage: a comparative study of election pledges and government policies in ten countries', Paper prepared for the 2012 Annual Meeting of the American Political Science Association, New Orleans, August 30- September 2, 2012.

Transparency International 2019, 'In Whose Interest? Political Integrity and Corruption in Africa', https://www.transparency.org/news/feature/political_ corruption_and_political_integrity_in_africa

Trent, J \& Friedenberg, R 2004, 'Political campaign communication', Rowan \& Littlefield, Lanham, MD.

UNDP 2016, 'Elections in the Sub-Saharan Africa: General Trends, Challenges and Opportunities', Report of the Maendeleo Policy Forum held on 18 August 2016 Ridge Arena, Swiss Spirit Hotel \& Suites Alisa, Accra, Ghana.

USAID 2014, 'Democracy, Human Rights, and Governance Strategic Assessment Framework'. Available at: https://www.usaid.gov/sites/default/files/ documents/1866/Master_SAF_FINAL\%20Fully\%20Edited\%209-28-15.pdf

Van Reybrouck, D 2016, 'Why elections are bad for democracy', The Guardian, 29 June. VOA 2019, 'Nigeria in Battle Against Fake News Ahead of Elections', 13 February. Wexler, A 2019, 'Fake News Rattles Nigerian Election Campaign', The Wall Street Journal, 15 February.

Wollack, K \& Doherty, I 2011,'Preface’, In N Kelly\& S Ashiagbor (eds.) Political Parties and Democracy in Theoretical and Practical Perspectives: Parliamentary Groups, National Democratic Institute (NDI). Available at: https://www.ndi.org/sites/ default/files/Political-parties-and-democracy-in-theoretical-and-practicalperspectives.pdf

World Bank, 2019, Social Contracts and World Bank Country Engagements: Lessons from Emerging Practices, IEG Meso Evaluation. Independent Evaluation Group, Washington, DC. 